\title{
Elevated Bronchoalveolar Lavage Fluid Histamine Levels in Allergic Asthmatics Are Associated with Methacholine Bronchial Hyperresponsiveness
}

\author{
Thomas B. Casale, Douglas Wood, Hal B. Richerson, Scott Trapp, \\ W. James Metzger, Donald Zavala, and Gary W. Hunninghake \\ Department of Internal Medicine, University of Iowa Hospitals and Clinics, Iowa City, Iowa 52242
}

\begin{abstract}
Using a sensitive single isotope enzymatic assay we measured bronchoalveolar lavage (BAL) fluid histamine in asymptomatic normal (nonallergic), allergic rhinitic, and allergic asthmatic subjects. Normal subjects were found to have little or no detectable amounts of histamine in BAL fluid $(11 \pm 11 \mathrm{pg} / \mathrm{ml})$, and few BAL fluid mast cells. In comparison, the allergic rhinitics and allergic asthmatics had much higher amounts of BAL fluid histamine (113 \pm 53 and $188 \pm 42 \mathrm{pg} / \mathrm{ml}$, respectively), and a significantly greater number of BAL fluid mast cells. Furthermore, despite having equivalent baseline pulmonary function values, allergic asthmatics with BAL fluid histamine levels $>100 \mathrm{pg} /$ $\mathrm{ml}$ required only $7 \pm 2$ breath units of methacholine to induce a $20 \%$ drop in forced expiratory volume in $1 \mathrm{~s}\left(F E V_{1}\right)\left(\mathrm{PD}_{20} F E V_{1}\right)$ while asthmatics with BAL fluid histamine levels $<100 \mathrm{pg} / \mathrm{ml}$ required $49 \pm 19$ breath units $(P<0.05)$. These data suggest that allergic asthmatics have ongoing lung mast cell degranulation that might contribute to the etiology of airway hyperresponsiveness.
\end{abstract}

\section{Introduction}

Allergic asthma is associated with marked hyperreactivity of the airways to a variety of stimuli (1-11). Many of the pathophysiologic features of allergic asthma can be attributed to mast cell mediators (1-3, 9-16). For example, histamine $(1,3,10)$, leukotrienes (9-11), prostaglandins (2), and other mediators (16) have been shown to induce airway constriction. The release of mediators from mast cells may occur as a result of both specific (e.g., allergen) and nonspecific (e.g., cold air) stimuli (17). Previous studies have suggested that there is a relationship between the allergic state and mast cell mediator release, and airway cholinergic hyperresponsiveness (18-21). Since released histamine is a marker for mast cell degranulation, assessment of bronchoalveolar lavage (BAL) ${ }^{1}$ fluid histamine is one means of evaluating local mast cell degranulation occurring in the airways.

Address reprint requests to Dr. Casale.

This work was presented in part at the 1986 Annual Meetings of the American Academy of Allergy and Immunology and the American Thoracic Society. 1986

Received for publication 2 June 1986 and in revised form 9 December

1. Abbreviations used in this paper: BAL, bronchoalveolar lavage; OPT, $O$-phthalaldehyde; $\mathrm{PD}_{20} F E V_{1}$, provocative methacholine dose producing a $20 \%$ decrease in the forced expiratory volume in $1 \mathrm{~s} ;\left({ }^{3} \mathrm{H}\right) \mathrm{SAMe}, \mathrm{S}$ (Methyl- ${ }^{3} \mathrm{H}$ )adenosyl-1-methionine.

J. Clin. Invest.

(c) The American Society for Clinical Investigation, Inc.

0021-9738/87/04/1197/07 \$1.00

Volume 79, April 1987, 1197-1203
The purpose of the present study was to determine the amount of histamine in BAL fluid from normal, allergic rhinitic, and allergic asthmatic subjects, and to ascertain if elevated BAL fluid histamine levels are associated with methacholine bronchial hyperresponsiveness. Our findings indicate that allergic subjects, and especially allergic asthmatic subjects, have significantly higher baseline BAL fluid histamine levels and mast cell numbers than nonallergic subjects. Furthermore, among the allergic asthmatics, higher BAL fluid histamine levels were associated with marked airway cholinergic hyperresponsiveness.

\section{Methods}

Reagents. Histamine diphosphate, 1-methylhistamine, $O$-phthalaldehyde (OPT) spray, toluidine blue, and Wright stains were purchased from Sigma Chemical Co., St. Louis, MO; acetone, chloroform, $\mathrm{NaOH}$, and $\mathrm{HCl}$ were from Fisher Scientific Co., Fair Lawn, NJ; Methacholine was from Baker Pharmaceuticals, Phillipsburg, NJ; $S$-[methyl- $\left.{ }^{3} \mathrm{H}\right]-$ adenosyl-l-methionine $\left(\left[{ }^{3} \mathrm{H}\right]-\mathrm{SAMe}\right)(65-78 \mathrm{Ci} / \mathrm{mmol})$ was from $\mathrm{New}$ England Nuclear Corp., Boston, MA; Whatman silica thin-layer chromatography (TLC) plates (LK6D) were from Whatman, Inc., Clifton, NJ.

Subjects. Subjects were adult, nonsmokers between the ages of 18 and $45 \mathrm{yr}$. Three groups were studied: mild seasonal allergic asthmatics, allergic rhinitics, and normal volunteers. Each subject had a complete medical history and physical examination and was skin tested intradermally with a routine battery of allergens (Center Laboratories, Port Washington, NY). A wheal size $5 \times 5 \mathrm{~mm}$ or greater than diluent control was considered positive. The allergic asthmatics had a history of mild seasonal asthma, were skin test positive to the appropriate allergens, and had a positive methacholine aerosol challenge. The criteria used to define a positive methacholine challenge are detailed below. The allergic rhinitics had no history of seasonal or perennial asthma, had positive skin tests to at least three common inhalant allergens with symptoms of rhinitis and conjunctivitis upon exposure to the allergens, and did not respond to 5 or less $\mathrm{mg} / \mathrm{ml}$ of methacholine during aerosol challenge. Normal controls had no symptoms of respiratory allergy, no immediate family history for allergic diseases, negative allergen skin tests, and a negative methacholine challenge.

Methacholine bronchoprovocation. Methacholine aerosol challenge was performed according to the procedure outlined by the American Academy of Allergy Committee on Standardization of Bronchoprovocation (22). A Johns Hopkins dosimeter was used to deliver concentrations of methacholine from 0.075 to $25 \mathrm{mg} / \mathrm{ml}$. Subjects were given five breaths of each concentration of methacholine by taking slow deep breaths from functional residual capacity to total lung capacity, without breath holding. A $20 \%$ drop in $F E V_{1}$ (below diluent baseline) which persisted for at least $5 \mathrm{~min}$ was considered a positive response. The provocative dose producing a $20 \%$ decrease in $F E V_{1}\left(\mathrm{PD}_{20} F E V_{1}\right)$ was calculated (22) and expressed as breath units $(1$ breath unit $=1 \mathrm{mg} / \mathrm{ml}$ inhaled methacholine).

$B A L$. These studies strictly conform to the guidelines for BAL in asthmatic subjects that were recently proposed by the National Institutes of Health, the American Academy of Allergy and Immunology, the American Thoracic Society, and the American College of Chest Physicians (23), as well as our own proposed guidelines (24). Prior to lavage and/ or bronchoprovocation, each subject was required to have an $F E V_{1}>60 \%$ 
of predicted and not less than $2 \mathrm{~L}$. Subsequently, each subject gave written informed consent for the study, which had been approved by the Human Subjects Review Committee of the University of lowa. Subjects were required to abstain from food or fluids the morning of the lavage or for $6 \mathrm{~h}$ before lavage if it was done in the afternoon. All allergic subjects were lavaged while clinically asymptomatic and "out of season" (i.e., when they were minimally or not exposed to allergens that elicited their symptoms). All subjects were prepared for BAL in a manner routine for all bronchoscopies, including BAL, at the University of Iowa (24). Atropine sulfate, $0.6 \mathrm{mg}$ i.m., and morphine sulfate, $8 \mathrm{mg}$ i.m., were given one half hour before the procedure. Xylocaine $(4 \%)$ was used topically to prevent coughing and to effect local anesthesia. Each individual also inhaled two puffs $(0.65 \mathrm{mg} / \mathrm{puff})$ of metaproterenol $15 \mathrm{~min}$ before bronchoscopy. Bronchoscopy was performed using a fiberoptic bronchoscope (BR-4B/2, Olympus Corp., New Hyde Park, NY). Lavage was performed by injecting five 20 -ml aliquots of warmed $\left(37^{\circ} \mathrm{C}\right)$ normal saline (total $=100 \mathrm{ml}$ ) into subsegmental bronchi. Immediately thereafter, suction was applied and the fluid recovered in a sterile trap. The lavage fluid was subsequently filtered through two layers of sterile gauze, and the cells were pelleted at $250 \mathrm{~g}$ for $5 \mathrm{~min}$. The lavage supernatants were then aliquoted and stored at $-70^{\circ} \mathrm{C}$ until histamine analyses were performed.

$B A L$ cell counts. The residual cell pellet (see above) was resuspended and washed twice in Hanks' balanced salt solution (without $\mathrm{Ca}^{2+}$ and $\mathrm{Mg}^{2+}$ ). A small sample of the cells was then counted in a Coulter counter (model FN, Coulter Electronics, Hialeah, FL). The total cell count was then divided by the BAL fluid volume and expressed as cells/ml BAL fluid.

Differential cell counts were done as previously described (24). Approximately 100,000 cells $(0.01 \mathrm{ml})$ were spun at $1,200 \mathrm{rpm}$ for $5 \mathrm{~min}$ onto a glass slide using a filter card and cytocentrifuge (Cytospin-2, Shandon Southern Instruments, Sewickley, PA). The cytocentrifuge preparations were then air dried and stained with Wright-Giemsa. Differential cell counts were obtained by identifying and counting 200 cells per slide using light microscopy. The differential cell counts are expressed as percentages of the total cell number.

Since mast cells were difficult to identify using the Wright Giemsa stain, at least one other cytocentrifuged slide (containing 25,000 cells) from each lavage sample was stained with $0.5 \%$ toluidine blue in $0.5 \mathrm{M}$ $\mathrm{HCl}$ for $2 \mathrm{~h}$. Using this staining technique and light microscopy, the metachromatic granules of mast cells are easily identified allowing the differentiation of these cells from other nucleated cells. The percentage of mast cells present in BAL fluid was calculated by counting the number of mast cells identified per 25,000 cells.

Determination of histamine levels. Histamine was assayed using a sensitive isotopic enzymatic assay (25) employing histamine- $N$-methyltransferase from rat kidneys that was prepared by the method of Shaff and Beaven (26). $10 \mu \mathrm{l}$ of BAL fluid or histamine standard $(0,100,200$, $400,600,800,1,000$, and $2,000 \mathrm{pg}$ histamine $/ \mathrm{ml}$ ) were incubated with $20 \mu$ l of histamine- $N$-methyltransferase, $0.5 \mu \mathrm{l}(236 \mathrm{nCi})$ of $\left[{ }^{3} \mathrm{H}\right] \mathrm{SAMe}$, and $10 \mu \mathrm{l}$ of $0.1 \mathrm{M}$ phosphate buffer, $\mathrm{pH} 7.4$, for $90 \mathrm{~min}$ at $37^{\circ} \mathrm{C}$. The reaction was stopped by the addition of $10 \mu \mathrm{l}$ of $3.8 \mathrm{M}$ perchloric acid. The samples were then centrifuged and $10 \mu \mathrm{l}$ of $10 \mathrm{~N} \mathrm{NaOH}$ and 300 $\mu$ l of chloroform were added to the resultant supernatants. The samples were subsequently mechanically shaken and then centrifuged once again. The aqueous layer was removed, the chloroform layer washed with 100 $\mu l$ of $3.3 \mathrm{~N} \mathrm{NaOH}$, and the tubes shaken and centrifuged as before. The chloroform layer was removed, evaporated to dryness under a stream of nitrogen, and then resuspended in chloroform in preparation for TLC. The samples plus $10 \mu \mathrm{l}$ of 1 -methylhistamine $(1 \mathrm{mg} / \mathrm{ml}$ in $50 \%$ methanol) were streaked onto activated TLC plates. The plates were developed in ascending fashion in an acetone/ammonium hydroxide mixture (95:10) to 10 to $15 \mathrm{~cm}$ (about 30 to $45 \mathrm{~min}$ ) and visualized under ultraviolet light after being sprayed with OPT. Each 1-methylhistamine spot was scraped from the plate, extracted in $0.1 \mathrm{~N} \mathrm{HCl}$, and assayed for radioactivity by liquid scintillation counting. Unknown values are calculated by comparing the mean counts per minute of triplicate samples with a calibration curve of the standard samples (100 to $2,000 \mathrm{pg} / \mathrm{ml}$ ) constructed by the least-squares method. The replicates of each sample usually differed from each other by $<15 \%$. To negate any possible influence that lavage fluid itself might have on the assay, the standard curve for histamine was routinely assayed in dialyzed BAL fluid. All results are provided as mean $\pm \mathrm{SE}$, and each statistical method employed is described in the text.

\section{Results}

Initial measurements of histamine added to dialyzed BAL fluid by an automated spectrofluorometric technique (27) indicated that the lowest level of sensitivity of this assay in our study was 1 to $2 \mathrm{ng} / \mathrm{ml}$. No histamine could be detected in $15 \mathrm{BAL}$ fluid samples assayed using the automated spectrophotometric technique (27). We therefore did two experiments to determine the stability of histamine in BAL fluid. Histamine at concentrations of 1 to $100 \mathrm{ng} / \mathrm{ml}$ was added to a BAL fluid sample, incubated for $3 \mathrm{~h}$ at room temperature, and then assayed using the automated spectrofluorometric technique. The amount of histamine added directly correlated to the amount of histamine measured $(r=0.99)$. Moreover, no loss of measurable histamine was found after 24-, 48-, and 72-h incubations of parallel lavage fluid samples to which $5 \mathrm{ng}$ histamine/ml was added. These data indicate that there were no substances present in the BAL fluid that interfered with the automated spectrofluorometric assay, and that histamine was stable in BAL fluid. The normal level of histamine in lavage fluid thus, is less than that which can be detected by an automated fluorometric technique (27).

We then used a sensitive single isotope enzymatic assay for measuring lavage fluid histamine (25). The assay involved extracting $\left[{ }^{3} \mathrm{H}\right]-1-$ methylhistamine generated by the enzyme $N$ methyltransferase acting on histamine in the presence of $\left[{ }^{3} \mathrm{H}\right] \mathrm{SAMe}$ into chloroform, and isolating the $\left[{ }^{3} \mathrm{H}\right]-1-$ methylhistamine by TLC. Histamine added to dialyzed lavage fluid could be accurately measured from 100 to $2,000 \mathrm{pg} / \mathrm{ml}$ using this assay (Fig. 1). The lowest limit of sensitivity of the assay (i.e., that point where the counts per minute were significantly, by $t$ test, above background) was $100 \mathrm{pg} / \mathrm{ml}$. Analyses of the net counts per minute above background induced by $100 \mathrm{pg} / \mathrm{ml}$ in 20 assays indicated a mean increase of 80 counts per minute, $P<0.001$ by paired sample $t$ test. Since the actual assay employs $10 \mu \mathrm{l}$ of sample, it is therefore, sensitive to at least $1 \mathrm{pg}$ of histamine.

To estimate the precision of the assay, one lavage fluid sample was assayed on 10 separate days, with the mean $\pm \mathrm{SE}$ and range of results shown in Fig. 2. Moreover, this same sample was assayed on 10 separate days after the addition of $1,000 \mathrm{pg}$ histamine $/ \mathrm{ml}$ to confirm the reproducibility of the assay at higher levels (Fig. 2). The mean net increase in lavage fluid histamine was $998 \mathrm{pg} / \mathrm{ml}$ in these later samples. Since most of the BAL fluid samples had values that were in the lower range, we also tested the reproducibility of the assay by repeatedly measuring the histamine content in one sample that had approximately $200 \mathrm{pg}$ histamine $/ \mathrm{ml}$. This sample was assayed on seven different days and had a mean $\pm S E$ histamine content of $215 \pm 15 \mathrm{pg} / \mathrm{ml}$ with a range of 180 to $298 \mathrm{pg}$ histamine/ml. Thus, these data indicate that the assay is very sensitive and reproducible at both high and low levels of histamine.

We then measured the BAL fluid histamine content in 69 samples: 36 from allergic asthmatic; 14 from allergic rhinitic; and 19 from normal subjects. The mean $\pm S E$ and range of results are presented in Fig. 3. The data were analyzed using the SAS Computer Software System (Cary, NC) on an IBM 370 computer. Using an analysis of variance $F$ test, the means of the three groups were found to be significantly different $(F=3.95$, 


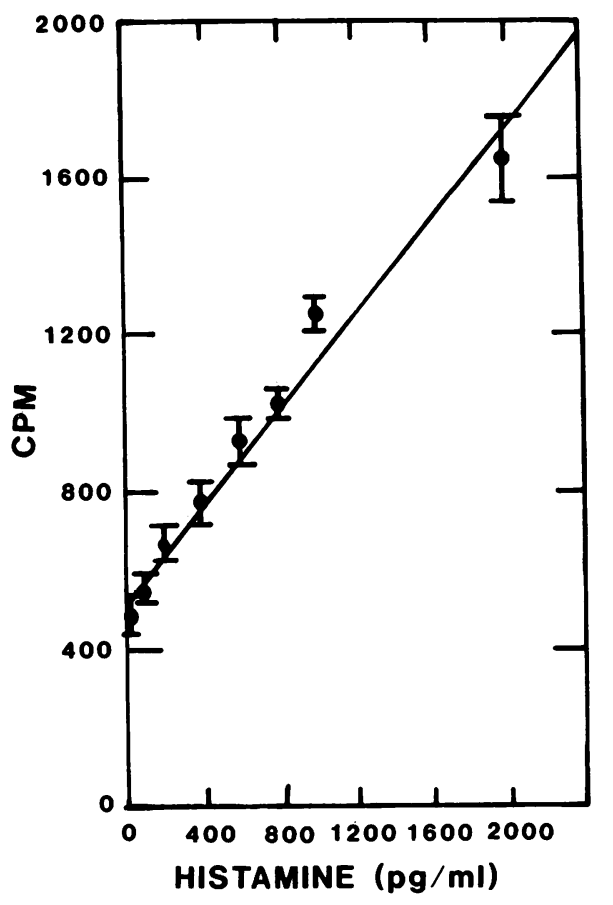

Figure 1. Standard curve of histamine added to dialyzed BAL fluid. The results represent the mean $\pm \mathrm{SE}$ from 20 standard curves. The line was determined by linear regression analysis $(r=0.99)$. At $100 \mathrm{pg} / \mathrm{ml}$, the counts per minute measured were significantly different from baseline $(P<0.001$ by paired sample $t$ test $)$.

$P=0.024)$. We then employed the Tukey-Kramer studentized range test for pairwise comparisons of the three groups. Allergic asthmatics were found to have a mean BAL fluid histamine level significantly greater than normals $(P<0.05)$ who had little or no detectable BAL fluid histamine (Table I). Allergic rhinitic subjects had a mean lavage fluid histamine level that was greater than normal, but less than allergic asthmatic subjects. However, the differences between the mean histamine level measured for those with allergic rhinitis and those measured for the normal and allergic asthmatic subjects were not significant by the TukeyKramer test.

As shown in Table I, the three groups did not have a significantly different number of lavage cells per milliliter of BAL fluid. Moreover, the differential cell counts were similar for all three groups. However, the allergic asthmatics did have a significantly higher percentage of eosinophils than either the allergic rhinitics or normal subjects. Both the allergic asthmatics and allergic rhinitics had significantly more mast cells than the normals (Table I). The metachromatic mast cells were easily identified using the toluidine blue stain. The mast cell granules stained red violet affording a striking contrast between these cells and other nucleated cells, which had a faint orthochromatic stain (Fig. 4).

Since the lowest limit of sensitivity of the histamine assay determined by paired sample $t$ test was $100 \mathrm{pg}$ histamine/ml (Fig. 1), values $<100 \mathrm{pg}$ histamine/ml were calculated by linear interpolation of the standard curve. The mean BAL fluid histamine level for the allergic asthmatics was $>100 \mathrm{pg} / \mathrm{ml}(188 \pm 42$ $\mathrm{pg} / \mathrm{ml}$ ), but many asthmatics had BAL fluid histamine levels that were either undetectable, or $<100 \mathrm{pg} / \mathrm{ml}$. We, therefore, compared the allergic asthmatics who had histamine levels $<100$ $\mathrm{pg} / \mathrm{ml}$ to those who had histamine levels $>100 \mathrm{pg} / \mathrm{ml}$ to determine if elevated BAL fluid histamine was associated with any

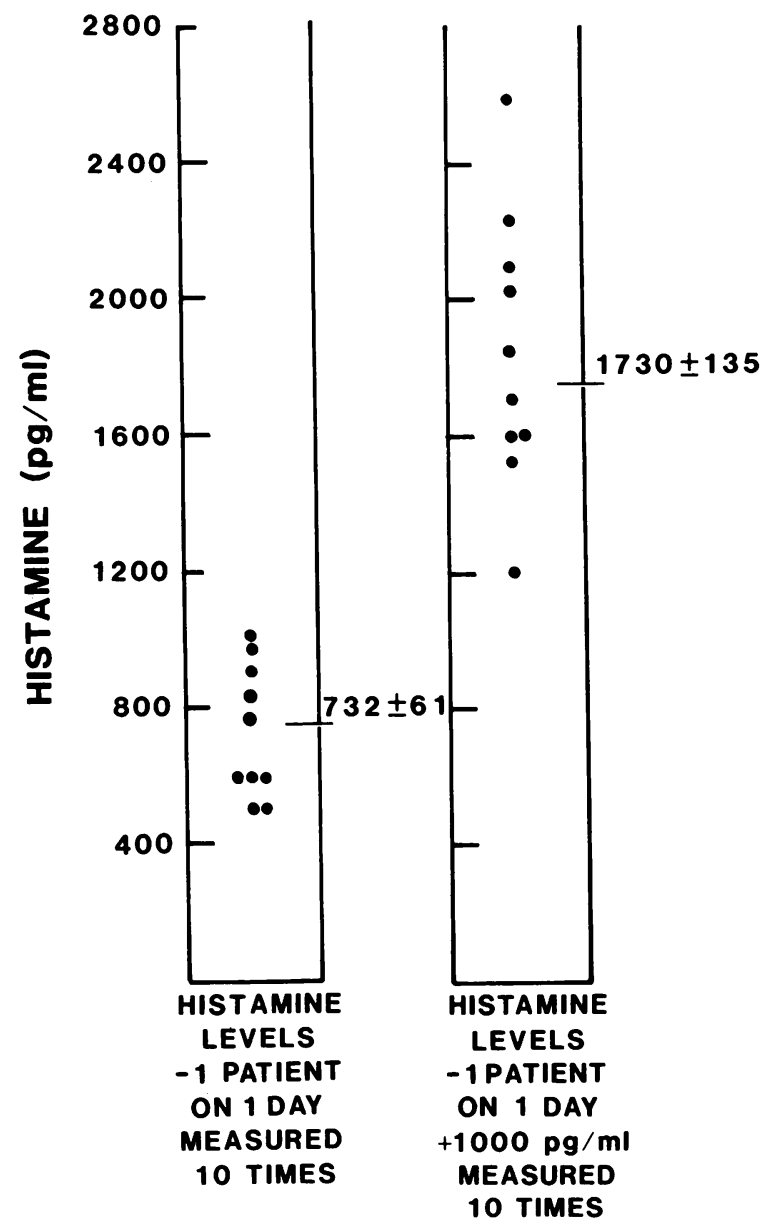

Figure 2. Two experiments testing the reproducibility and accuracy of the histamine assay. The results are expressed as the mean $\pm \mathrm{SE}$. In the left panel, BAL fluid collected from one patient at one time was assayed on 10 separate days. In the right panel, the same BAL fluid sample was assayed 10 times after the addition of $1,000 \mathrm{pg}$ histamine $/ \mathrm{ml}$. The mean net increase in histamine measured from baseline was 998 $\mathrm{pg} / \mathrm{ml}$.

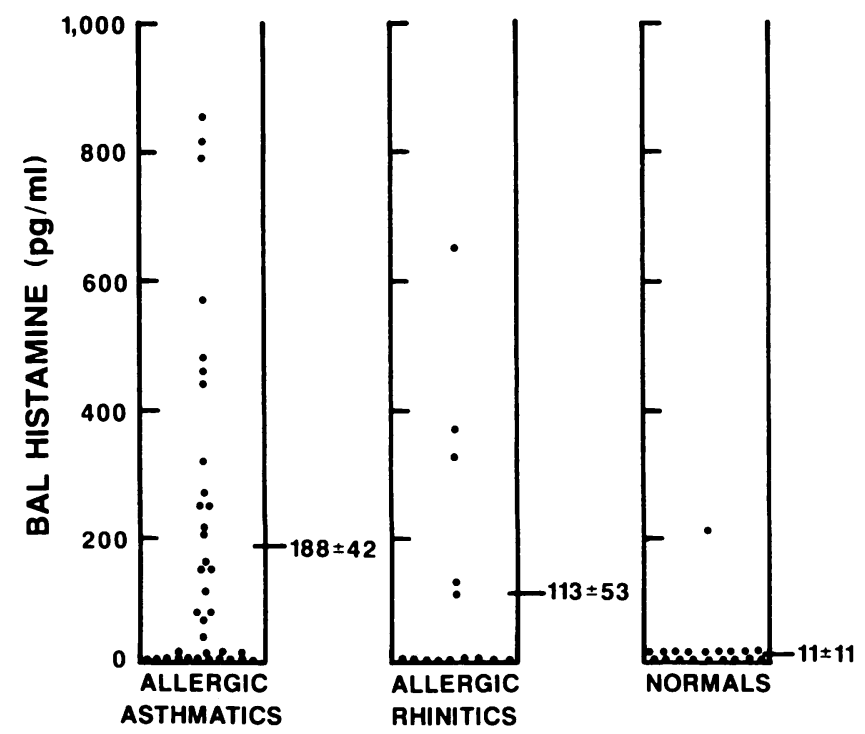

Figure 3. BAL histamine levels in three groups of subjects. Values are expressed as the mean \pm SE. Allergic asthmatics had a significantly higher mean histamine level versus the normal subjects $(P<0.05$ by the Tukey-Kramer Test). 


\begin{tabular}{lccc}
\hline & Allergic asthmatics & Allergic rhinitics & Normals \\
\hline Number of subjects & 36 & 14 & 19 \\
Histamine $(p g / m l)^{*}$ & $188 \pm 42$ & $113 \pm 53$ & $11 \pm 11$ \\
Lavage cells/ml & $110,403 \pm 8,623$ & $117,677 \pm 12,039$ & $133,677 \pm 13,544$ \\
\% Eosinophils & $1.0 \pm 0.3$ & $0.2 \pm 0.1$ & $0.2 \pm 0.1$ \\
\% Mast cells & $0.05 \pm 0.01$ & $0.07 \pm 0.02$ & $0.02 \pm 0.01$
\end{tabular}

Statistical significance $(P<0.05)$ calculated by Tukey-Kramer Studentized Range Test. * Allergic asthmatics significantly different from normals. ${ }^{\ddagger}$ Allergic asthmatics significantly different from allergic rhinitics and normals. Normals significantly different from allergic rhinitics and allergic asthmatics.

other factors (Table II). Despite equivalent baseline pulmonary function values, the asthmatic patients who had higher BAL fluid histamine levels had significantly lower methacholine $\mathrm{PD}_{\mathbf{2 0}}$ values. However, there were no significant differences in the numbers or percentages of BAL fluid cells between the two asthmatic groups. Thus, in allergic asthmatics, an elevated BAL fluid histamine level is associated with increased airway responsiveness to inhaled methacholine, but not to baseline pulmonary function values or BAL fluid cellular content.

\section{Discussion}

These data clearly indicate that a sensitive isotope enzymatic assay $(25,26)$ developed for the measurement of plasma histamine can be used to measure BAL fluid histamine. The assay used for this study was sensitive to at least $100 \mathrm{pg}$ histamine/ml ( $1 \mathrm{pg} / \mathrm{sample}$ ), and was very reproducible at both high and low ranges of histamine. Using this assay, normal subjects were found to have little or no detectable amounts of histamine in BAL fluid. In contrast, allergic asthmatics had significantly higher amounts of histamine in BAL fluid compared with normals ( $P$ $<0.05$ ). Allergic rhinitics were found to have BAL fluid histamine levels that were intermediate to those measured for normal subjects and allergic asthmatics. Moreover, the BAL fluid samples were obtained at a time when the allergic subjects were asymptomatic and not exposed (or minimally exposed) to the allergens that elicited their symptoms. The amount of histamine measured in the BAL fluid from the allergic subjects thus may be lower than that present when these subjects are exposed to clinically significant levels of allergen and are symptomatic.

It is unlikely that the drugs used to premedicate the subjects prior to lavage contributed to the elevated histamine levels noted in allergic asthmatics. It would be expected that atropine (cholinergic antagonist) and metaproterenol (beta-agonist) would either have no effect, or inhibit nonspecific mast cell histamine release $(28,29)$. Although morphine may cause mast cell degranulation, it does so by a nonimmunologic mechanism (30). Thus, morphine would be predicted to cause histamine release in all subjects equally. Topical xylocaine instilled into the upper airways would not be expected to result in degranulation of luminal mast cells located in subsegmental bronchi. It is also unlikely that these drugs would interfere with the histamine assay since, with the possible exception of metaproterenol, none of these drugs would be expected to achieve measurable quantities in the airway lumen. Moreover, the histamine assay uses a radioenzymatic technique with a TLC separation, making it a highly specific assay. Finally, since all three study groups received the same drugs, any elevation in BAL fluid histamine due to effects of the drugs on mast cells or on the histamine assay would be expected to be noted for all three groups equally. Thus, the elevated levels of histamine measured in BAL fluids from allergic asthmatics probably reflect mast cell degranulation occurring naturally in the airways and not factitiously due to the drugs employed as premedications.

There exists the possibility that the elevated histamine levels measured in the BAL fluid of asthmatics is due to the lavage process itself. That is, the actual physical process of exposure of mast cells to saline and suction through the bronchoscope could conceivably cause mast cell degranulation. We, therefore, obtained 11 BAL fluid samples (8 from asthmatics and 3 from normal subjects) and reaspirated these samples through the bronchoscope. The measured histamine levels did not significantly change after passing them through the bronchoscope a second time. Thus, it appears unlikely that the elevated BAL fluid histamine levels measured for the allergic asthmatics occurred as a result of the lavage procedures.

Human lung mast cells contain $\sim 4$ to $10 \mathrm{pg}$ histamine/cell $(31,32)$ and release about $20 \%$ of their histamine content when stimulated with anti-IgE (31). Therefore, assuming a mean of $20 \%$ histamine release, one would expect that normal subjects and allergic asthmatics would need $\sim 10$ to 15 , and 150 to 250 mast cells/ml BAL fluid, respectively, to produce the measured amounts of BAL fluid histamine. The normal subjects did in fact have about 15 mast cells/ml BAL fluid, but the allergic asthmatics had an average of only 50 mast cells/ml BAL fluid. This observation is consistent with previous studies (32) in which allergic asthmatics were found to have a significantly greater number of mast cells/ml BAL fluid than normal. However, the number of mast cells predicted to be necessary for the production of the measured asthmatic BAL fluid histamine levels is greater than the number actually obtained. It is, therefore, quite likely that a portion of the histamine measured in BAL fluid comes from extraluminal mast cells. An electronmicroscopic study demonstrated that as much as $2 \%$ of the alveolar wall in man is occupied by mast cells (33). An average concentration of 350 mast cells $/ \mathrm{mm}^{2}$ of alveolar wall was found in normal lung. These mast cells were found within $1 \mu \mathrm{m}$ from the luminal surface. Moreover, there was ultramicroscopic evidence of extraluminal mast cell degranulation. Thus, it is not unexpected to find that the number of luminal mast cells identified by light microscopy does not correlate well with the measurement of free histamine in BAL fluid.

There are several other possible reasons for the lack of correlation between BAL fluid histamine levels and the numbers 

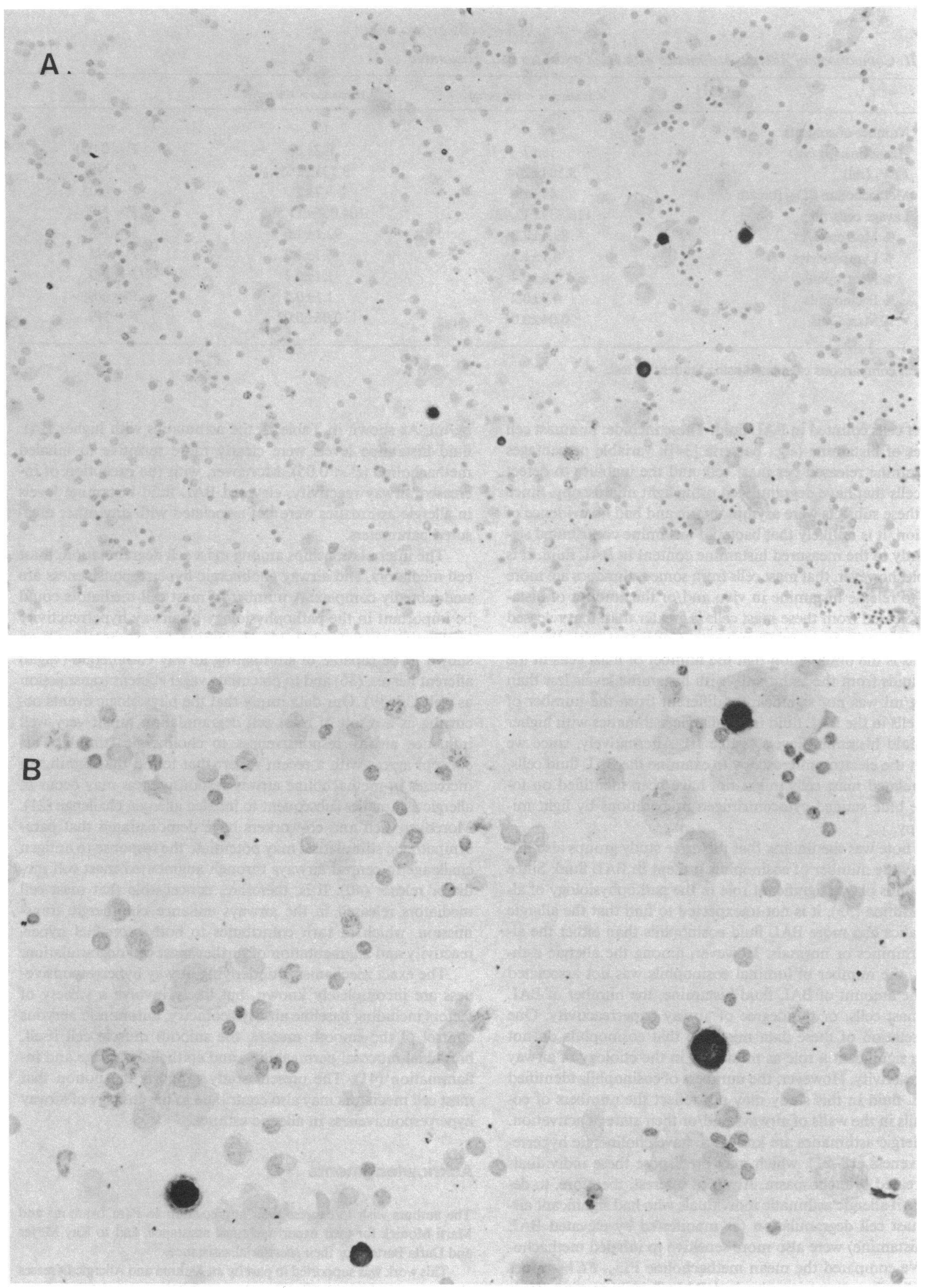

Figure 4. Photomicrograph of a cytocentrifuged preparation of BAL cells from a patient with allergic asthma stained with toluidine blue. A low $(100 \times)$ power $(A)$ and high $(250 \times)$ power $(B)$ view showing the easily identified dark staining mast cells. 
Table II. Comparison of Allergic Asthmatics with High and Low BAL Histamine

\begin{tabular}{|c|c|c|c|}
\hline & Histamine $<100 \mathrm{pg} / \mathrm{ml}$ & Histamine $>100 \mathrm{pg} / \mathrm{ml}$ & \\
\hline Number of subjects & 19 & 17 & \\
\hline Histamine $(p g / m l)$ & $15 \pm 7$ & $382 \pm 60$ & $P<0.001$ \\
\hline$F E V_{1}(\mathrm{ml})$ & $3,504 \pm 234$ & $3,735 \pm 245$ & $P=$ NS \\
\hline Methacholine $\mathrm{PD}_{20}$ (breath units) & $49 \pm 19$ & $7 \pm 2$ & $P<0.05$ \\
\hline Lavage cells/ml & $116,739 \pm 12,931$ & $104,066 \pm 11,596$ & $P=\mathrm{NS}$ \\
\hline \% Macrophages & $89.4 \pm 2.2$ & $92.1 \pm 1.6$ & $P=\mathrm{NS}$ \\
\hline \% Lymphocytes & $8.1 \pm 1.9$ & $5.7 \pm 1.4$ & $P=\mathrm{NS}$ \\
\hline \% Neutrophils & $1.6 \pm 0.4$ & $1.1 \pm 0.3$ & $P=\mathrm{NS}$ \\
\hline \% Eosinophils & $0.9 \pm 0.2$ & $1.1 \pm 0.5$ & $P=\mathrm{NS}$ \\
\hline \% Mast Cells & $0.04 \pm 0.01$ & $0.06 \pm 0.02$ & $P=\mathrm{NS}$ \\
\hline
\end{tabular}

Statistical comparisons calculated using Student's $t$ test.

of mast cells counted in BAL fluid. These include: nonmast cell sources of histamine (e.g., bacteria [34]); variable percentages of histamine released per mast cell; and the inability to detect mast cells that have degranulated using light microscopy. Since all of these subjects were asymptomatic and had no evidence of infection, it is unlikely that bacterial histamine contributed significantly to the measured histamine content in BAL fluid. It is possible, however, that mast cells from some asthmatics are more likely to release histamine in vivo and/or the amount of histamine released from these mast cells is greater than that released from mast cells from other subjects. Consistent with this hypothesis is the observation that the number of mast cells in the BAL fluids from the asthmatics with histamine levels less than $100 \mathrm{pg} / \mathrm{ml}$ was not significantly different from the number of mast cells in the BAL fluid from allergic asthmatics with higher BAL fluid histamine levels (Table II). Alternatively, since we did not use electron microscopy to examine the BAL fluid cells, degranulated mast cells might not have been identified on toluidine blue stained cytocentrifuged preparations by light microscopy.

Of note was the finding that the three study groups also differed by the number of eosinophils present in BAL fluid. Since eosinophils play a significant role in the pathophysiology of allergic asthma (35), it is not unexpected to find that the allergic asthmatics had more BAL fluid eosinophils than either the allergic rhinitics or normals. However, among the allergic asthmatics, the number of luminal eosinophils was not associated with the amount of BAL fluid histamine, the number of BAL fluid mast cells, or the degree of airway hyperreactivity. One interpretation of these data might be that eosinophils do not play as significant a role as mast cells in the etiology of airway hyperreactivity. However, the numbers of eosinophils identified in BAL fluid in this study may not reflect the numbers of eosinophils in the walls of airways and/or their state of activation.

Allergic asthmatics are known to have cholinergic hyperresponsiveness (18-21), which may predispose these individuals to increased bronchospasm. It was of interest, therefore, to determine if allergic asthmatic individuals who had significant airway mast cell degranulation (as manifested by elevated BAL fluid histamine) were also more sensitive to inhaled methacholine. We compared the mean methacholine $\mathrm{PD}_{20} F E V_{1}$ values from allergic asthmatics who had BAL fluid histamine levels $>100 \mathrm{pg} / \mathrm{ml}$ to the $\mathrm{PD}_{20}$ values from those who had levels $<100$ $\mathrm{pg} / \mathrm{ml}$. As shown in Table II, the asthmatics with higher BAL fluid histamine levels were clearly more sensitive to inhaled methacholine $(P<0.05)$. Moreover, with the exception of increased airway reactivity, elevated BAL fluid histamine levels in allergic asthmatics were not associated with any other measured parameters.

The interrelationships among mast cell degranulation, mast cell mediators, and airway cholinergic hyperresponsiveness are undoubtedly complex. A number of mast cell mediators could be important in the pathophysiology of airway hyperreactivity in allergic asthma $(1-3,9-16)$. Histamine, for example, has been shown to be capable of stimulating airway cholinergic (vagal) afferent nerves, (36) and to potentiate vagal efferent transmission as well (37-39). Our data imply that the physiologic events occurring as a result of mast cell degranulation might very well influence airway responsiveness to cholinergic stimuli. This concept agrees with a recent report that found that significant increases in methacholine airway responsiveness may occur in allergic asthmatics subsequent to inhaled allergen challenge (21). Moreover, Leff and co-workers have demonstrated that parasympathetic stimulation may potentiate the response to antigen challenge in central airways through augmented mast cell mediator release (40). It is, therefore, conceivable that mast cell mediators released in the airways enhance cholinergic transmission, which in turn contributes to both bronchial hyperreactivity and augmentation of further mast cell degranulation.

The exact mechanisms underlying airway hyperresponsiveness are incompletely known, but likely involve a variety of factors including baseline airway geometry, autonomic nervous control of the smooth muscle, the smooth muscle cell itself, bronchial mucosal permeability, and epithelial damage and inflammation (41). The present study supports the notion that mast cell mediators may also contribute to the etiology of airway hyperresponsiveness in allergic asthma.

\section{Acknowledgments}

The authors wish to express their appreciation to Pam Iwamoto and Marti Monick for their expert technical assistance, and to Kay Meyer and Darla Bartels for their secretarial assistance.

This work was supported in part by an Asthma and Allergic Diseases Center grant AI-19093 NIAID and grant RR59, General Clinical Research Center Branch, National Institutes of Health. 


\section{References}

1. Juniper, E. F., P. A. Frith, C. Dunnett, D. W. Cockcroft, and F. E. Hargreave. 1978. Reproducibility and comparison of responses to inhaled histamine and methacholine. Thorax. 33:705-710.

2. Thomson, N. C., R. Roberts, J. Bandouvakis, H. Newball, and F. E. Hargreave. 1981. Comparison of bronchial responses to prostaglandin $\mathrm{F}_{2_{\alpha}}$ and methacholine. J. Allergy Clin. Immunol. 68:392-398.

3. Eiser, N. M., J. Mills, P. D. Snashall, and A. Guz. 1981. The role of histamine receptors in asthma. Clin. Sci. 60:363-370.

4. O'Byrne, P. M., G. Ryan, M. Morris, D. McCormack, N. L. Jones, J. L. C. Morse, and F. E. Hargreave. 1982. Asthma induced by cold air and its relationship to nonspecific bronchial responsiveness to methacholine. Am. Rev. Respir. Dis. 125:281-285.

5. Boushey, H. A., M. J. Holtzman, J. R. Sheller, and J. A. Nadel. 1980. State of the art. Bronchial hyperreactivity. Am. Rev. Respir. Dis. 121:389-413.

6. Orehek, J. 1981. Neurohumoral control of airway caliber. In Respiratory Physiology III. J. G. Widdicombe, editor. University Park Press, Baltimore, MD. 1-74.

7. Boushey, H. A. 1985. Asthma and bronchial hyperreactivity. Possible role of disturbance in autonomic regulation. Prog. Respir. Res. 19: 124-136.

8. Thomson, N. C. 1983. Neurogenic and myogenic mechanisms of nonspecific bronchial hyperresponsiveness. Eur. J. Respir. Dis. 64(Suppl.): 206-211.

9. Drazen, J. M. 1986. Inhalation challenge with sulfidopeptide leukotrienes in human subjects. Chest. 89:414-419.

10. Bisgaard, H., S. Groth, and F. Madsen. 1985. Bronchial hyperreactivity to leucotriene $\mathrm{D}_{4}$ and histamine in exogenous asthma. $\mathrm{Br}$. Med. J. 290:1468-1471.

11. Smith, L. J., P. A. Greenberger, R. Patterson, R. D. Krell, and P. R. Bernstein. 1985. The effect of inhaled leukotriene $D_{4}$ in humans. Am. Rev. Respir. Dis. 131:368-372.

12. Casale, T. B., and M. Kaliner. 1984. Allergic reactions in the respiratory tract. In Immunology of the Lung and Upper Respiratory Tract. J. Bienenstock, editor. McGraw-Hill, New York. 326-344.

13. Marone, G. 1985. The role of basophils and mast cells in the pathogenesis of pulmonary diseases. Int. Arch. Allergy Appl. Immunol. 76:70-82.

14. Wasserman, S. I. 1984. The human lung mast cell. Environ. Health Perspect. 55:259-269.

15. Lagunoff, D. 1983. The role of mast cells in asthma. Exp. Lung Res. 4:121-135.

16. Cuss, F. M., C. M. S. Dixon, and P. J. Barnes. 1986. Effects of inhaled platelet activating factor on pulmonary function and bronchial responsiveness in man. Lancet. ii:189-192.

17. Metcalfe, D. D., M. Kaliner, and M. A. Donlon. 1981. The mast cell. CRC Crit. Rev. Immunol. 3:23-74.

18. Kaliner, M., J. H. Shelhamer, P. B. Davis, L. J. Smith, and J. C. Venter. 1982. Autonomic nervous system abnormalities and allergy. Ann. Intern. Med. 96:349-357.

19. Szentivanyi, A. 1968. The beta adrenergic theory of the atopic abnormality in bronchial asthma. J. Allergy. 42:203-225.

20. Curry, J. J. 1947. Comparative action of acetyl-beta-methyl choline and histamine on the respiratory tract in normals, patients with hay fever, and subjects with bronchial asthma. J. Clin. Invest. 26:430-438.

21. Bar-Sela, S., D. P. Schlueter, S. R. Kitt, A. J. Sosman, and J. N. Fink. 1985. Antigen-induced enhancement of bronchial reactivity. Chest. 88:114-116.

22. Chai, H., R. S. Farr, L. A. Froelich, D. A. Mathison, J. A. McLean, R. R. Rosenthal, A. L. Sheffer, II, S. L. Spector, and R. G. Townley. 1975. Standardization of bronchial inhalational challenge procedures. J. Allergy Clin. Immunol. 56:323-327.

23. Bernstein, I. L., H. A. Boushey, R. M. Cherniack, J. N. Fink,
J. D. Fulmer, E. J. Goetzl, R. A. Goldstein, S. S. Hurd, S. J. Ram, L. M. Lichtenstein, H. Y. Reynolds, R. M. Senior, R. A. Simon, P. Ward, and D. C. Zavala. 1985. Summary and recommendations of a workshop on the investigative use of fiberoptic bronchoscopy and bronchoalveolar lavage in asthmatic patients. Chest. 88:136-138.

24. Metzger, W. J., K. Nugent, H. B. Richerson, P. Moseley, R. Lakin, D. Zavala, and G. W. Hunninghake. 1985. Methods for bronchoalveolar lavage in asthmatic patients following bronchoprovocation and local antigen challenge. Chest. 87:16S-19S.

25. Dyer, J., K. Warren, S. Merlin, D. D. Metcalfe, and M. Kaliner. 1982. Measurement of plasma histamine: description of an improved method and normal values. J. Allergy Clin. Immunol. 70:82-87.

26. Shaff, R. E., and M. A. Beaven. 1979. Increased sensitivity of the enzymatic isotopic assay for tissue histamine: measurement of histamine in plasma and serum. Ann. Biochem. 94:425-430.

27. Siraganian, R. P. 1974. An automated continuous-flow system for the extraction and fluorometric analysis of histamine. Anal. Biochem. 57:383-394.

28. Kaliner, M. 1977. Human lung tissue and anaphylaxis. I. The role of cyclic GMP as a modulator of the immunologically induced secretory process. J. Allergy Clin. Immunol. 60:204-211.

29. Orange, R. P., W. G. Austen, and K. F. Austen. 1971. Immunological release of histamine and slow reacting substance of anaphylaxis from human lung. I. Modulation by agents influencing cellular levels of cyclic 3',5'-adenosine monophosphate. J. Exp. Med. 134(Suppl.):136148.

30. Casale, T. B., S. Bowman, and M. Kaliner. 1984. Induction of human cutaneous mast cell degranulation by opiates and endogenous opioid peptides: evidence for opiate and nonopiate receptor participation. J. Allergy Clin. Immunol. 73:775-781.

31. Schulman, E. S., D. W. MacGlashan, Jr., S. P. Peters, R. P. Schleimer, H. H. Newball, and L. M. Lichtenstein. 1982. Human lung mast cells: purification and characterization. J. Immunol. 129:2662-2667.

32. Tomioka, M., S. Ida, Y. Shindoh, T. Ishihara, and T. Takishima. 1984. Mast cells in bronchoalveolar lumen of patients with bronchial asthma. Am. Rev. Respir. Dis. 129:1000-1005.

33. Fox, B., T. B. Bull, and A. Guz. 1981. Mast cells in the human alveolar wall: an electronmicroscopic study. J. Clin. Pathol. 34:13331342.

34. Sheinman, B. D., J. L. Devalia, R. J. Davies, S. J. Crook, and S. Tabaqchali. 1986. Synthesis of histamine by Haemophilus influenzae. Br. Med. J. 292:857-858.

35. Ayars, G. H., L. C. Altman, G. J. Gleich, D. A. Loegering, and C. B. Baker. 1985. Eosinophil and eosinophil granule-mediated pneumocyte injury. J. Allergy Clin. Immunol. 76:595-604.

36. Karczewski, W., and J. G. Widdicombe. 1969. The role of the vagus nerve in the respiratory and circulating reactions to anaphylaxis in rabbits. J. Physiol. (Lond.). 201:293-304.

37. Loring, S. H., J. M. Drazen, J. R. Snapper, and R. H. Ingram, Jr. 1978. Vagal and aerosol histamine interactions on airway responses in dogs. J. Appl. Physiol. 45:40-44.

38. Kikuchi, Y., H. Okayama, M. Okayama, H. Sasaki, and T. Takishima. 1984. Interaction between histamine and vagal stimulation on tracheal smooth muscle in dogs. J. Appl. Physiol. 56:590-595.

39. Stewart, A. G., D. C. Thompson, and M. R. Fennessy. 1985. Acetylcholine and histamine interact supra-additively on bronchomotor tone in guinea pigs in vivo: a possible consequence of the relationship between airways resistance and calibre. Arch. Intl. Pharmacodyn. Therapie. 273:33-46.

40. Leff, A. R., N. P. Stimler, N. M. Munoz, T. Shioya, J. Tallet, and C. Dame. 1986. Augmentation of respiratory mast cell secretion of histamine caused by vagus nerve stimulation during antigen challenge. J. Immunol. 136:1066-1073.

41. Boushey, H. A., M. J. Holtzman, J. R. Sheller, and J. A. Nadel. 1980. State of the art. Bronchial hyperreactivity. Am. Rev. Respir. Dis. $121: 389-413$ 